\title{
Storytelling we współczesnym teatrze w kontekście kultury afrykańskiej*
}

W zaproszeniu na konferencję Storytelling in Contemporary Theatre, która odbyła się w Krakowie w dniach 15-17 listopada 2007 roku, można było przeczytać:

Najnowsze zmiany w teatrze i pisanych dlań tekstach [...] to wynik długotrwałych poszukiwań takich form ekspresji, które potrafią zapewnić aktywny i kolektywny udział widzów w teatralnym wydarzeniu. Odgrywa on istotną rolę w ustanawianiu społecznych więzi i potwierdzaniu zbiorowej tożsamości ${ }^{1}$.

Odwołując się do „oralnych korzeni teatru”, autorzy zaproszenia określają storytelling jako „efektywny środek definiowania na nowo relacji między sceną a widownią”. Stwierdzają wreszcie, że „zachodzące współcześnie fundamentalne zmiany świadczą o istotnej modyfikacji rozumienia pojęcia teatr oraz relacji między tekstem, sceną i widzami". Jako ktoś, kto zajmuje się afroamerykańskim i afrykańskim dramatem oraz afrykańskim dramatem diaspory, muszę zapytać o punkt widzenia, z którego storytelling zaliczyć można do nowych lub „najświeższych tendencji we współczesnym teatrze". Z jakiego punktu widzenia można mówić o zmianie koncepcji teatru i podstawowych relacji między tekstem, sceną i widownią? Storytelling w kontekście kultury afrykańskiej to bardzo dawna praktyka performatywna, która nigdy ani nie znalazła się na marginesie, ani nie wyszła $\mathrm{z}$ mody wśród potomków czarnej kultury. Dlatego teraz chciałabym, po pierwsze, spojrzeć na storytelling zarazem historycznie i współcześnie; pokazać, jak się go dziś praktykuje w Afryce i w diasporach na terenie Stanów Zjednoczonych. Dialog między performerem a słuchaczami w tego typu praktykach to kluczowy element, który czarni dramatopisarze przenoszą na teren instytucjonalnego teatru. Aby udowodnić, jak powszechnie korzysta się z technik storytelling we współczesnym czarnym teatrze, najpierw sięgnę wstecz, do moich wcześniejszych badań nad twórczością nigeryjskiego autora Femi Osofisana, a następnie zaproponuję bardziej szczegółową analizę dwóch afroamery-

* Wykład Storytelling we wspótczesnym teatrze $w$ kontekście kultury afrykańskiej otworzył drugi dzień obrad międzynarodowej konferencji naukowej Storytelling in Contemporary Theatre zorganizowanej przez Katedrę Dramatu Uniwersytetu Jagiellońskiego w Krakowie w dn. 15-17 listopada 2007.

1 http://www.firt-iftr.org/firt/site/conferences.jsp 
kańskich sztuk, na temat których jeszcze nie pisałam. Postaram się udowodnić, że w kontekście afrykańskiej kultury, Once Upon Four Robbers (Dawno temu czterech rozbójników) Osofisana oraz Gem of the Ocean (Klejnot $\mathrm{z}$ oceanu) Augusta Wilsona, podobnie jak Las Meninas Lynn Nottage $^{2}$ pokazują, że teatr traktowany jako publiczne forum zmusza widzów do aktywnego uczestnictwa w poszukiwaniu wspólnych, kolektywnych wartości. Badanie dramatu i teatru $\mathrm{w}$ tym kontekście to nie turystyczna wycieczka do egzotycznych krajów ani urlop od poważnych studiów nad teatrem. Ten dramat i teatr oferuje możliwość poznania innej kultury na jej własnych prawach, zmuszając do stawiania pytań na temat uniwersalnych cech takiego teatru, który chce tworzyć i podtrzymywać społeczne więzi.

Chciałabym rozpocząć od zdefiniowania kilku podstawowych terminów. Kiedy mówię o „kontekście afrykańskiej kultury”, wcale nie myślę o biologicznej spuściźnie, którą ludzie z Afryki przekazują swoim potomkom. Raczej, zapożyczając się u teoretyka kultury Raymonda Williamsa, chciałabym zasygnalizować istnienie wspólnego zbioru praktyk, wartości, dzieł artystycznych i procesów, dzięki którym potomkowie mieszkańców Afryki nadają sens swemu światu i odróżniają się od innych grup społecznych. Z historycznego punktu widzenia na kontynencie afrykańskim istniały kultury pluralistyczne, hybrydyczne i dynamiczne, rozwijane przez ludy o odmiennej przeszłości, językach i zwyczajach. Jednak mimo różnic w czasie i miejscu odznaczały się one pewnymi podobieństwami pod względem filozoficznego i praktycznego stosunku do świata. Transatlantycki handel niewolnikami zapoczątkował globalną modernizację, a podstawowe dla niej praktyki dominacji i dehumanizacji Zachód ujął w ramy ideologicznego projektu, który Innych zmienił w ofiary ludobójstwa i niewolników z powodu odmiennej rasy i stanu posiadania, a ich ziemie poddał kolonizacji3 ${ }^{3}$. Wtedy potomkowie ludów Afryki zetknęli się z kultura i pewnymi praktykami społecznymi Europejczyków, które sobie przyswoili - oczywiście ci, którzy znaleźli się w „Nowym Swiecie”. Afrykańczycy przyswoili sobie także kulturę rdzennych mieszkańców obu Ameryk oraz przechowali i w dużym stopniu na nowo wymyślili

${ }^{2}$ F. Osofisan, Once Upon Four Robbers (a Play), Heinemann Educational Books Nigeria PLC, Ibadan 1991; A. Wilson, Gem of the Ocean, Theatre Communications Group, New York 2006; L. Nottage, Las Meninas, w: tegoż, „Crumbs from the Table of Joy" and Other Plays, Theatre Communications Group, New York 2004.

${ }^{3}$ P. Gilroy, The Black Atlantic: Modernity and Double Consciousness, Harvard University Press, Cambridge 1993; S.V. Hartman, Scenes of Subjection: Terror, Slavery, and Self-Making in Nineteenth Century America, Oxford University Press, New York 1997; B. Hesse, Creolizing the Political: a Genealogy of the African Diaspora, Duke University Press, Durham (w druku). 
własne „oryginalne” kultury. Po części w odpowiedzi na hegemonię Zachodu wypracowali swój własny sposób rozumienia kolektywnej odmienności, określanej jako „afrykańskość” czy „czarność”.

Teraz chciałabym omówić zespół praktyk performatywnych, a szczególnie ich kategorii znanej jako „oratura”. Teatr w ostatnich latach XX wieku należy definiować nie tyle jako widowisko czy rozrywkę, ale jako „sposób zdobywania wiedzy, ucieleśniony proces, dzięki któremu ludzie tworzą i konceptualizują swój świat, negocjują związki z innymi oraz sobie i innym przedstawiają własną rzeczywistość"4. W ramach czarnej kultury oratura to kategoria performansu. Choć często traktuje się to określenie jako synonim terminu „literatura oralna”, skąd pochodzą jej językowe korzenie ${ }^{5}$, to przecież oratura oznacza szerszej pojęty „system estetyczny"6, obejmujący gesty, śpiew, sztuki wizualne, muzykę, zagadki, opowieści i przysłowia jako sposoby ekspresywnej komunikacji. Termin „oratura" stworzyli dwaj badacze z Ugandy w latach sześćdziesiątych, Pio Zirimu i Austin Bukenya, przeciwstawiając się europejskiemu priorytetowi literatury nad oralnością. Następnie został on upowszechniony przez kenijskiego pisarza i badacza Ngugi wa' Thiong'o i innych jako część ich projektu modyfikacji kolonialnego systemu edukacji przez położenie nacisku na rodzime zasady przekazywania wiedzy i praktycznych umiejętności. Sam termin jest bardzo popularny w afroamerykańskich dyskursach, ale praktyki performansowe typowe dla oratury, podobnie jak zawarty w niej ideologiczny projekt, mają swoje amerykańskie odpowiedniki. Kulturowa wartość tego, co oralne/performatywne, wzrosła w Stanach Zjednoczonych w chwili, kiedy potomkom afrykańskich ludów odmówiono dostępu do edukacji i pełnych praw obywatelskich.

Różne rodzaje oratury zakładają określony typ relacji społecznych. Ngugi powołuje się na przysłowie: „Słodko śpiewa, kiedy inni mu wtórują. Lecz i słodkie piosenki w ten sposób dłużej trwają" . Podkreśla ono wagę zaangażowania publiczności, która aktywnym udziałem odpowiada na wezwanie wykonawcy. Dlatego snucie opowieści często zaczyna otwierająca formuła. Wypowiadając ją, prosi się pozostałych o pozwolenie na zabranie głosu. Jedno $\mathrm{z}$ przedstawień $\mathrm{w}$ Kenii $\mathrm{w}$ latach dziewięćdziesiątych, na przykład, zaczynało się od wezwania (tłumaczenie $\mathrm{z}$ języ-

${ }^{4}$ D. Soyini Madison, J. Hamera, Introduction: Performance Studies at the Intersections, w: The Sage Handbook of Performance Studies, red. D. Soyini Madison, J. Hamera, Sage Publications, Thousand Oaks 2006, s. XI-XXV.

5 I. Okpewho, African Oral Literature: Backgrounds, Character, and Continuity, Indiana UP, Bloomington 1992.

${ }^{6} \mathrm{Ngugi}$ wa' Thiong'o, Penpoints, Guns, and Dreams: Toward a Critical Theory of the Arts and the State in Africa, Clarendon Press, Oxford 1998.

7 Cyt. za J. Roach, Cities of the Dead: Circum-Atlantic Performance, Columbia UP, New York 1996, s. 12. 
ka kiswahili) „Opowieść! Opowieść?”. Zebrani odpowiadali: „Przyjdź opowieści! Przyjdźcie fikcyjne historie/ozdoby! Przyjdź słodyczy! Ogarnij nas! Ogarnij nas!”8 „Słodycz” czy estetyczna przyjemność staje się w konsekwencji dynamicznej interakcji między wykonawcą a publicznością jako współwykonawcą tak wielka, że powstająca energia „ogrania wszystkich”, przynosząc korzyść całej społeczności i każdemu z osobna. Wymiana pytań i odpowiedzi to także reguła w czasie mszy w czarnych kościołach chrześcijańskich, gdyż kapłan oczekuje głośnych reakcji w czasie, kiedy wygłasza kazanie. Może na przykład starać się o aprobatę dla określonego poglądu, nakłaniając zgromadzonych: „Chcę usłyszeć wasze amen”. Albo też napiętnować ich milczenie, mówiąc: „Wcale mnie nie słuchacie. Pozwólcie więc, że powtórzę...” Wierni natomiast mogą wspierać wygłaszającego kazanie, wolając: „Prosimy, pastorze! Powiedz nam!” czy skrytykować jego wysiłki słowami: „Dość, dość tego. Wracaj do kazania!”. Oznacza to, że kapłan powinien spróbować lepiej wyrazić swoje myśli i uczucia, by poruszyć wiernych. Odwiedzając miejsca świeckie, na przykład prowadzony przez czarnoskórych zakład fryzjerski, czy choćby takie wydarzenia jak organizowany przez stowarzyszenie czarnych studentów „pokaz stepowania” czy konkurs tańca, zobaczymy podobne modele interakcji. Zgodnie $\mathrm{z}$ nimi słuchacze/patrzący powtarzają, komentują, wspierają czy rzucają wyzwanie wykonawcy w czasie jego występu' ${ }^{9}$. We wszystkich tych rodzajach oratury komunikacja wymaga aktywnego dialogu, antyfony czy formuły pytanie-odpowiedź, w której stawką jest kondycja zbiorowości. Właśnie zbiorowość ma tu kluczowe znaczenie, ponieważ ten obraz świata nie znosi binaryzmu, który oddziela jednostkę od grupy, świeckie od religijnego, obiektywne od subiektywnego; ten obraz świata traktuje te elementy jako istniejące obok siebie $\mathrm{w}$ pewnym kontinuum, gdzie kategorie i wartości za każdym razem określa specyficzny dla danej sytuacji kontekst. Tak więc performatywne wydarzenie - w kościele, u fryzjera, na potańcówce czy politycznym zebraniu - powinno zwiększyć energię i zasób płynącej z doświadczenia wiedzy wszystkich uczestników, lecz nic nie gwarantuje sukcesu, skoro przypadek, płynność i wielogłosowość ogrywa w nim swoją rolę.

Teraz weźmy pod uwagę specyficzne cechy storytelling. Badacz Isidore Okpewho w książce African Oral Literature przypomina, że w tra-

${ }^{8}$ S. Mshai Mwangola, Performing Our Stories, Performing Ourselves: In Search of Kenya's Uhuru Generation, rozprawa doktorska przygotowana na Northwestern University (w druku).

9 E.C. Fine, Soulstepping: African American Step Shows, University of Illinois Press, Urbana 2003; J. Malone, Stepping: Regeneration through Dance in African American Fraternities and Sororities, w: Steppin' on the Blues: The Visible Rhythms of African American Dance, University of Illinois Press, Urbana 1996. 
dycyjnym afrykańskim kontekście, w ramach relacji rodzinnych, storytelling to najczęściej jeden $\mathrm{z}$ elementów szerszego świata perfomatywnych praktyk, takich jak dziecięce zabawy w chowanego, rozmowy dorosłych o minionym dniu i śpiewanie piosenek. Nawet spotkanie w celu snucia opowieści często poprzedza opowiadanie zagadek czy/i przysłów, które po części pełnią pedagogiczną funkcję, rozwijając umysłowe zdolności, poszerzając słownictwo i kulturowe dziedzictwo czy poczucie wspólnoty wśród młodzieży. Jak już zaznaczyłam, storyteller rozpoznawalną formułą zwykle sygnalizuje, że rozpoczyna opowieśćc ${ }^{10}$. Natomiast słuchacze muszą wyrazić zgodę na jego propozycję. Wtedy on relacjonuje w szczegółach kilka luźno powiązanych epizodów; w każdym sam odgrywa role różnych postaci i może zwracać się do słuchaczy, żeby coś zaśpiewali czy zatańczyli. Jeśli któryś ze słuchaczy ma wrażenie, że narracji brakuje tempa czy wyobraźni, to może sam przejąć opowieść albo przejść do innej11.

Często tematy opowieści nie pochodzą z własnego doświadczenia, ale $\mathrm{z}$ kolektywnych źródeł. I to $\mathrm{z}$ wielu względów. Opowiadający może chcieć nie tylko zabawić słuchaczy i wzmocnić emocjonalne związki między zebranymi, ale także skomentować daną sytuację w symbolicznej formie, by załagodzić jakieś rodzinne czy zbiorowe napięcia; może też chcieć podpowiedzieć pożądane modele zachowań albo przypomnieć dzieje rodziny czy zbiorowości. Ponieważ zwykle treść, gatunek czy bieg wydarzeń znane są większości słuchaczy, pełnią oni funkcję krytycznych odbiorców, zwracając uwagę na sposób opowiadania danej historii. Zauważają nie tylko gestykę, intonację czy zasadę uobecniania fikcyjnych postaci, ale także oryginalność wykonawcy i jego improwizacyjne talenty w modyfikowaniu istniejących już wersji, przetwarzaniu epizodów czy wprowadzaniu nowych elementów, postaci i piosenek z podobnych historii, by dostosować prezentowaną wersję do konkretnej okazji. „Skupiają oni uwagę [...] na umiejętnościach wykonawcy, który musi okazać "luz" lub mistrzostwo w wesołej [czy „gorącej”] sytuacji improwizacji, choć ma świadomość swojej potencjalnej klęski i odrzucenia przez zbiorowość"12. Jak pisze krytyk sztuki Robert Farris Thompson, zdolność do zachowa-

10 I. Okpewho, African Oral Literature: Backgrounds, Character and Continuity, lndiana UP, Bloomington 1992, s. 222.

11 R.D. Abrahams, African Folktales: Traditional Stories of the Black World, Pantheon Books, New York 1983; W. Bascom, African Dilemma Tales: An Introduction, w: African Folklore, red. R.M. Dorson, Doubleday and Company, Garden City, NY 1972; S.L. Richards, Ancient Songs Set Ablaze: The Theatre of Femi Osofisan, Howard UP, Washington, D.C. 1996.

12 S.L. Richards, Ancient Songs..., op. cit., s. 82. 
nia luzu to także świadectwo tego, co Jorubowie z Nigerii nazywają ase, siłą sprawczą, ponieważ zachowanie „wdzięku pod presją" wymaga od wykonawcy iskry naturalnego talentu i dowodzi, że ma on „dość wiary w siebie, żeby stawić czoła wszystkim trudnym sytuacjom"13.

\section{Once Upon Four Robbers}

Wiedząc już, jak funkcjonuje storytelling w nie-teatralnych kontekstach afrykańskich i w diasporze, przyjrzyjmy się sztuce Femi Osofisana Once Upon Four Robbers. Tytuł tej wystawionej po raz pierwszy w Nigerii w 1978 roku sztuki sugeruje rodzimej publiczności dwie idee, które zwykle nie idą ze sobą w parze. Po pierwsze, zwrot „once upon” (dawno temu) zdaje się zapowiadać ludową opowieść czy baśń, która służy dydaktycznym celom, ucząc młodzież pożądanych zachowań. Natomiast wprowadzenie czwórki uzbrojonych napastników sugeruje, że będzie to rzecz współczesna, podejmująca problem społecznych przyczyn napadów z bronią i publicznych egzekucji przestępców. Całość zaczyna śpiew narratora, który oczekuje interakcji pytanie-odpowiedź typowej dla storytelling. Obiecuje „dawną i nowoczesną” opowieść o „niebezpiecznych rozbójnikach na drogach / Piratach, przyczynie łez", którzy poprosili go o ochronę przed wspólczesnymi ludźmi, gotowymi do każdej zbrodni w pogoni za pieniądzem. Kiedy widzowie podejmują refren piosenki, aktorzy i muzycy siedzący dotąd między nimi wchodzą na scenę, pozdrawiają się, wybierają kostiumy i role. Już na wstępie dochodzi do przeciwstawienia dwóch typów przestępców, zaś tworzenie iluzji w przytomności oglądających zrównuje tworzenie sztuki z tworzeniem czy możliwością zmiany świata, który ona powinna odzwierciedlać.

Po tym krótkim wprowadzeniu następuje opowieść o bandzie rozbójników bez przywódcy, którego publicznie stracono. Przeczuwając, że trzej mężczyźni i kobieta chcą go obrabować, starzec o imieniu Aafa wypomina im, że nie mają żadnego godnego zajęcia. Oferuje im dar, który zapewni im bogactwo, jeśli tylko obiecają nigdy nie okradać biednych, rabować tylko w publicznych miejscach i nie zabijać. Obiecany dar to piosenka, do której każdy z nich musi dodać jedną zapamiętaną linijkę. Kiedy ją zaśpiewają, zaczaruje ona słuchaczy, każąc im tańczyć i pozostawić dobytek bez nadzoru. Banda odkrywa, że czary starego człowieka naprawdę działają. Śpiewają, a potem okradają handlarki na placu targowym, ale - jak było do przewidzenia - ktoś z nadmiernej chciwości zaczyna okradać też pozostałych. Zrodzona $\mathrm{z}$ tego kłótnia prowadzi do

13 Tamże, s. 16. 
tego, że ich przywódca zostaje zastrzelony, oni uciekają, szukając bezpiecznej kryjówki, a policja zagarnia dla siebie pieniądze i dobra obrabowanych. W kilku epizodach sytuacja rozbójników, handlarek i źle opłacanej policji zostaje tak udramatyzowana, że prośby o współczucie w obliczu zdrady przeciwstawiają się wezwaniu ofiar do zemsty, oficjalny apel o przestrzeganie prawa kłóci się z kwestią przyjacielskich zobowiązań, tworząc pułapkę równoważnych wartości, z której nie ma łatwego wyjścia. Pojawia się ponownie stary Aafa. Zatrzymuje akcję i, po raz kolejny przekraczając "czwartą ścianę”, która dotąd pozwalała widzom spokojnie obserwować wydarzenia, zwraca się do nich z wezwaniem do podjęcia decyzji: „Czy należy zastrzelić rozbójników? Co faktycznie rodzi przestępczość w społeczeństwie, gdzie niewielu bogaci się niepomiernie kosztem większości? Jak takie uczucia, jak współczucie i braterstwo, winny funkcjonować, by zapewnić społeczny porządek, w którym dostatnie życie dla wszystkich zostanie wyrwane ze szczęk pewnej śmierci w kapitalistycznym systemie ekonomicznym?"

Didaskalia zaznaczają, że publiczność powinna domagać się egzekucji rabusiów. Wtedy złodzieje zagrają tę scenę w wolnym tempie niczym pajace na sznurku, przy akompaniamencie irytujących dźwięków zbyt głośnej wojskowej muzyki. Jeśli widzowie opowiedzą się za uwolnieniem przestępców, wtedy złodzieje znów zaśpiewają swoją piosenkę, zaczarowując i okradając tak kupców na scenie, jak publiczność na widowni. Jak pokazuje każde $\mathrm{z}$ tych rozwiązań, wybór ma określone konsekwencje, które nie zgadzają się z zakończeniem typowym dla baśni, czyli „i żyli długo i szczęśliwie". Takie postawienie sprawy domaga się refleksji, trudnych dyskusji w grupie i ewentualnie zbiorowych działań. Osofisan tak określił cel, w jakim napisał swoją sztukę:

Nie chodziło mi o jasne oddzielenie potępienia od nagrody, ale o zmuszenie widzów do tego, by zaczęli stawiać pytania i zgłaszać wątpliwości pod adresem obowiązujących konwencji i dominujących poglądów. Chciałem sprowokować ich do takiego zbadania samych siebie, jakiego jeszcze nie podejmowali. $W$ ten sposób scena przestaje być miejscem uspokajającego zrozumienia, a staje się rozsadnikiem niepokoju i tym samym katalizatorem społecznych i politycznych zmian $^{14}$.

Powtarzając, a zarazem modyfikując, poglądy Bertolta Brechta15, Osofisan projektuje wizję teatru jako sfery publicznej, gdzie widzowie

14 F. Osofis an, Literary Theatre After the Generals - a Personal Itinerary, TS, International Federation for Theatre Research conference, Summer 2007.

15 Formułując problem w ten sposób, chcialabym zwrócić uwagę na inne aspekty kultury czarnoskórych. Innymi słowy, „obśmiewam” czy niebezpośrednio komentuję zasadę, że dobry performer powinien nie tylko wykazywać się dogłębną znajomością tekstów, 
mogą zobaczyć swoją codzienność w całej jej pełni, z wszystkimi wewnętrznymi sprzecznościami. Wezwani do zaangażowania w dialog i wyobrażenia sobie lepszego świata współdziałają z aktorami tworząc to, co znawca performansu D. Soyini Madison nazywa „performansami możliwości”, które mogą - lecz nie muszą - zmaterializować się w pozateatralnym świecie ${ }^{16}$.

\section{Gem of the Ocean}

Przechodząc do następnej sztuki, Gem of the Ocean Augusta Wilsona, chciałabym skupić się na tym, jak schematy narracyjne codziennych rozmów przenosi się na scenę. Nieżyjący już August Wilson zamierzał napisać sztukę o Afroamerykanach, ukazując w niej wszystkie dekady XX wieku. Gem of the Ocean, której premiera odbyła się w 2003 roku, to dziewiąta sztuka tego cyklu, choć podejmuje problematykę czarnych w pierwszych dekadach ubiegłego wieku. Akcja rozgrywa się w domu Ciotki Ester, której wiek odpowiada stuleciom obecności Afrykańczyków w Stanach Zjednoczonych - tej tajemnicy nie próbuje rozwikłać żadna z postaci - zaś cały dramat pokazuje między innymi Obywatela Barlowa, młodego człowieka, który przybył do tego domu, aby „obmyć” swoją duszę i przezwyciężyć duchowy kryzys. Barlow ukradł wiadro pełne gwoździ, ale ktoś inny, mężczyzna o imieniu Garrett Brown, został oskarżony o kradzież. Zdesperowany Brown skoczył do rzeki i utonął, bo wolał śmierć niż publiczne potępienie jako złodzieja. Obawiający się konsekwencji wyjawienia prawdy, Obywatel Barlow spodziewał się, że Brown wybierze życie, a nie śmierć, zaś teraz mówi Ciotce Ester: „Czuję, jakbym wewnątrz miał dziurę. Jak nie będę uważał, to przez tę dziurę wszystko ze mnie wypłynie. Co robić, panno Tyler?".

Ciotka Ester odpowiada w następujący sposób: „Znam człowieka, który hodował świnie. Wielkie, ogromne, stare świnie. Dla niego wszystko zaczynało się od świni. I na świni się kończyło. Gdzie nie spojrzał, widział świnie. Widział świnie na niebie i świnie na ziemi. Swinia była dla niego centrum życia. Któregoś dnia jakiś człowiek zabił wszystkie jego świnie”. Kiedy Ciotka Ester opowiada historię o świniach, jej odpo-

które poprzedzały jego/jej opowieść, ale także musi stworzyć dyskurs, który modyfikuje istniejące teksty i wprowadza jakieś nowe elementy. Henry Louis Gates, Jr. określa tę praktykę mianem „powtórzenia z krytyczną różnicą”; wspólczesna dramatopisarka amerykańska, Suzan Lori Parks, nazywa tę praktykę „powtórz i przyspiesz”; zaś lingwista i krytyk z Joruby, Olabiyi Yai, stwierdza, że itan, często (błędnie) tłumaczone jako „historia", również rządzi się tą zasadą.

16 D. Soyini Madison, Critical Ethnography, op. cit., s. 172-178. 
wiedź na jego dylematy może się wydać Obywatelowi Barlow cokolwiek niejasna. Niewątpliwie wielu dzisiejszym widzom również może się początkowo wydawać, że jej odpowiedź jest zupełnie od rzeczy i świadczy tylko o zaawansowanej demencji. Ale ponieważ Barlow reprezentuje pokolenie, którego ojcowie znali jeszcze niewolnictwo, odpowiedź Ciotki Ester może dla niego brzmieć znajomo, bo została sformułowana w sposób typowy dla wielu starszych czarnoskórych, szczególnie tych, którzy cieszyli się znacznym autorytetem moralnym lub religijnym w społecznościach niewolników. Opowiada ona historię, która mogłaby się wydarzyć na każdej farmie. Oczywiście, ozdabia historyjkę kłamstwem, bo przecież nikt nie widzi świń na niebie, ale to kłamstwo zostaje wprowadzone w tak plastyczny sposób, aby oddać wartą zapamiętania prawdę o moralnym problemie farmera.

Ciotka Ester kontynuuje swoją opowieść: „Stracił wszystko. Stracił centrum swego życia, bo nie miał go w sobie. Nie znajdowało się tam, skąd nikt nie mógłby go zabrać”. I aby upewnić się, że Obywatel Barlow nie przegapi analogii między historią o świniach i swoim nieszczęściem, kontynuuje: „Widzi pan, Obywatelu Barlow, w tej chwili to wiadro gwoździ stoi w centrum pańskiego życia. A ma pan tylko jedno życie, panie Obywatelu. To pańskie życie. Nikt inny nie ma do niego prawa". I aby zmusić Obywatela Barlow, aby zrozumial, dlaczego Garrett Brown wybrał śmierć, dodaje: „Powiedział, lepiej umrzeć w prawdzie niż żyć w kłamstwie. Dzięki temu może powiedzieć, że jego życie warte jest więcej niż wiadro gwoździ. A ile warte jest pańskie życie, panie Obywatelu?". I nim Obywatel Barlow zdąży odpowiedzieć, zaczyna kolejną historię, tym razem o biblijnym Piotrze, który trzykrotnie zaparł się Chrystusa. Zastanawia się głośno, czy inaczej niż Piotr, pan Obywatel wykorzysta okazję, by odpokutować winy, a potem opowiada dalej: „Jeśli koło nie obraca się tak, jak powinno, wtedy się je naprawia. Znam człowieka, który chciał naprawić koło. Obracało się w tył, zamiast w przód. Chcial je naprawić, ale jak skończył, to koło przestało się obracać. Trzeba uważać. Pozory lubią mylić". Ponownie Ciotka Ester mówi z pomocą symbolicznych obrazów i opowiada o społecznym kontekście, który Obywatel Barlow niewątpliwie rozpoznaje. Jednak powiązania między historią a życiem tego młodego człowieka nie są tak oczywiste, ani dla Barlowa, ani dla publiczności. Nie pozwalając ani jemu, ani nam na chwilę refleksji lub dodatkowe pytania, Ciotka Ester obiecuje pomóc, opowiadając jeszcze jedną historię, tym razem o Mieście Kości. Ale Barlow usłyszy ją dopiero wtedy, gdy znajdzie dwa pensy, które leżą gdzieś na ziemi obok siebie. Zapytana po wyjściu Barlowa, czemu kazała mu odnaleźć dwa pensy, Ciotka Ester odpowiada, że ci, którzy przychodzą do niej po radę, niczego by nie zrozumieli, gdyby po prostu podała im rozwiązanie. 
Zamiast tego, jak mówi, „lepiej pokazać im, jak odnaleźć je na własną rękę".

Historie o obsesji na punkcie świń, Piotrze wypierającym się Chrystusa i kole kręcącym się w złym kierunku stanowią rodzaj autorefleksyjnej krytyki procesu dramatyzacji. Oczywiście, interesująca historia z plastycznymi opisami i niejednoznacznym przesłaniem angażuje widza w sytuacje performatywnego i wspólnego konstruowania znaczenia. Prócz tego, jak stwierdza lingwistka Geneva Smitherman, pisząc o języku Afroamerykanów w latach siedemdziesiątych XX wieku, „dawać świadectwo oznacza mówić prawdę, opowiadając jakąś "historię»" tak w przestrzeni świeckiej, jak religijnej. Odnotowując fakt, że dobry storyteller opowiada historię zazwyczaj w nielinearnym porządku, konkluduje: „Relacjonowanie tych wydarzeń w życiowo prawdopodobnej formie odtwarza duchową rzeczywistość dla słuchaczy, którzy w tym momencie z drugiej ręki doświadczają tego, co było doświadczeniem mówiącego. Swiadectwo to zatem nie zwykły i prosty komentarz, ale dramatyczna narracja i akt odtworzenia wobec wspólnoty własnych emocji i doświadczeń. W ten sposób człowieczeństwo mówiącego zostaje potwierdzone przez grupę, niwelując także dystans między nimi"17.

Sposób opowiadania Ciotki Ester przywodzi także wyraźne skojarzenia ze sposobem postępowania wróżbitów w tradycji Joruba, o czym pisałam w innym miejscu w kontekście sztuk Femi Osofisana i dramatu Wilsona Joe Turner's Come and Gone (Joe Turner przyszedł i poszedł). Wróżenie można rozumieć jako prototypową sytuację tworzenia sensów w ramach paradygmatu dramatycznego. W tradycji Joruba osoba przechodząca duchowy kryzys szuka porady u kapłana wyszkolonego w geomantycznym systemie wróżb zwanym Ifa, gdzie mądrość zakodowana została w tomach i pojedynczych wersach, których kapłan uczy się na pamięć. „Dyskurs Ifa jest wysoce poetycki, bowiem posługuje się takimi strategiami retorycznymi, jak ezoteryczne słownictwo, gry słów, onomatopeje, hiperbole, uosobienia, powtórzenia i fragmenty do recytacji"18. Zależnie od układu rozrzuconych muszelek lub orzechów kapłan recytuje odpowiednie wersety odnoszące się do doświadczenia ludzi, których historie w jakiś sposób przypominają historię szukającego porady. Kapłan tak długo przytacza kolejne opowieści, aż w końcu przybysz rozpozna $w$ jednej $z$ nich odbicie swojej sytuacji. Ten system jest dynamiczny, bo szukający porady sam musi zdecydować, która narracja odnosi się do niego, a potem złożyć samodzielnie ofiarę, rozumianą jako akt zarazem

17 G. Smitherman, Talkin and Testifyin: The Language of Black America, Wayne State UP, Detroit 1977, s. 150.

18 S.L. Richards, Ancient Songs..., op. cit., s. 120. 
magiczny i materialny. W akcie tym śmierć ofiary, w wyniku rytualnej transformacji, zamienia się w energię życiową, zdolność do efektywnego działania zwaną ase, która ma „umożliwić mu doświadczenie $\mathrm{z}$ drugiej ręki tego, czego wcześniej nigdy nie widział, ani nawet sobie nie wyobrażał, aby osiągnąć harmonię $\mathrm{z}$ całą społecznością żyjących, umarłych, a nawet tych, którzy istnieją między kategorią człowieka i nieczłowieka. Cały ten proces jest bezustannie narażony na przerwanie czy pojawienie się nieprzewidzianych i przypadkowych wydarzeń, zmuszających szukającego porady do modyfikacji narracji o związku $\mathrm{z}$ otaczającym go światem"19.

Jak Obywatel Barlow, publiczność przychodzi do teatru w nadziei, że pozna jakąś głęboką prawdę o świecie. Ciotka Ester i inne postacie przedstawiają jej serię opowieści i odgrywanych sekwencji, które niekoniecznie tworzą spójną całość. Widzowie zostają w ten sposób zmuszeni do podjęcia wysiłku w celu zrozumienia tego, jaka jest ostateczna wartość życia Obywatela Barlowa. Zależnie od umiejętności aktorów i całego zespołu, mogli się z nim utożsamić, odbyć metaforyczną podróż do przerażająco wspaniałego Miasta Kości w głębi Atlantyku, gdzieś na szlaku handlu niewolnikami, gdzie umarły tysiące niewolników, a potem razem z nim wynurzyć się bogatsi o lekcję odpowiedzialności za samego siebie, wynurzyć się jako osoba, której tożsamość definiuje się w relacji ze społecznością. Jeśli zdajemy sobie sprawę, że nasza indywidualna podmiotowość kształtuje się zawsze w relacjach $\mathrm{z}$ innymi, z wydarzeniami zewnętrznymi wobec nas, a także $z$ dotykającymi nas dziełami sztuki, wtedy poprzez caly łańcuch skojarzeń, który uruchamia interpretacja Gem of the Ocean, zaczynamy rozumieć, że przenikliwość Sethe, bohaterki powieści Toni Morisson Ukochana, osadzonej w realiach XIX wieku, stanowi wyzwanie dla Obywatela Barlow w 1904 roku, które z kolei, jak mi się wydaje, stanowi wyzwanie dla nas w 2007 roku. Sethe stwierdza bowiem gorzką prawdę, że „wyzwolić się to jedno; wejść w posiadanie wolnego już siebie to coś zupełnie innego"20.

\section{Las Meninas}

Jako ostatnią chciałabym omówić sztukę Las Meninas Lynn Nottage, wyróżnionej w 2007 roku przez Fundację MacArthura tytułem geniusza, przyznawanym Amerykanom wyróżniającym się twórczym talentem. Już sam tytuł Las Meninas podsuwa skojarzenie z namalowanym

19 Tamże, s. 125.

${ }^{20}$ T. Morrison, Beloved, New American Library, New York 1987, s. 95. 
w XVI wieku obrazem Velazqueza, na którym ustawienie hiszpańskiej infanty, jej pokojówek i samego malarza stało się powodem powstania wielu prac naukowych na temat relacji między rzeczywistością i jej reprezentacją. Michel Foucault pisze o tym obrazie, że „patrzy on na scenę, którą sam przedstawia. Pokazuje czystą wzajemność obserwującego i obserwowanego lustra"21. Nottage nawiązuje, a zarazem odmiennie przedstawia - „powtarza z kluczową różnicą” w kontekście kultury afroamerykańskiej - tę problematykę, osadzając akcję swojej sztuki na innym europejskim dworze, na dworze Ludwika XIV i jego żony Marii Teresy. Narrację prowadzi w tym dramacie Luiza Maria Teresa, córka z nieprawego łoża Marii Teresy i czarnego karła-niewolnika; córka, o której Ludwik XIV twierdził, że urodziła się martwa. Całość stanowi próbę odpowiedzi na pytanie, ,jak odzyskać wymazaną historię”, kiedy do dyspozycji ma się tylko kobiece plotki i portret zatytułowany Czarna zakonnica $z$ Moret. Chciałabym jeszcze przez chwilę zatrzymać się na tym fragmencie, gdzie czarnoskóry karzeł Nabo opowiada historię ówczesnej elity, zaś my możemy oglądać udramatyzowany proces zmiany czy wręcz znikania historii, która przecież też jest rodzajem opowieści.

Nabo, przysłany w pudełku jako prezent dla królowej Marii Teresy, która sama była ślubnym prezentem pieczętującym więź Hiszpanii z Francją, opowiada o swoim dzieciństwie we Francji, kiedy jako niewolnik nie rozumial, dlaczego jego pan ma zwyczaj nosić peruki i makijaż. Opowiada tę historię Ludwikowi XIV na dworze, który słynął z wyszukanych rytuałów utwierdzających władzę króla. Choć Nottage nie opatruje teks-tu prawie żadnymi wskazówkami dla aktorów, tę narrację konstruuje $\mathrm{w}$ taki sposób, aby aktor musiał raz po raz zmieniać się z narratora w jedną z postaci opowiadanej historii. Czytelnik może sobie bez trudu wyobrazić, jak czarnoskóry karzeł odgrywa „piękno” ubioru swego pana oraz swoje przerażenie w chwili, kiedy widzi, że w łóżku jego pana śpi stary, łysy mężczyzna. Zbulwersowany przekroczeniem dobrych obyczajów, Nabo wyciąga mężczyznę z łóżka, aby za chwilę odkryć perukę oraz to, że jego pan w rzeczywistości „przechowuje swoją twarz w słoiku z różem i w pudełku z pudrem". Karzeł wyznaje, że wahał się, czy wpuścić swego pana z powrotem do domu i ponieść konsekwencje własnej niewiedzy, czy teź zostawić go na zimnie, aby oszalał. Kiedy król żąda, aby Nabo wyjawił, jak skończyła się historia, ten odpowiada po prostu: "On oszalał”.

Ta sekwencja, stanowiąca typowy przykład storytelling, to zarazem interesująca krytyka określonej klasy społecznej i świadectwo wyrafino-

${ }^{21}$ M. Foucault, The Order of Things: An Archaeology of the Human Sciences, Random House, Inc., New York, 1994, s. 14. 
wania afrykańskiej diaspory i żywotności tego drugiego obiegu kulturowego w Europie, o czym w dużej mierze dziś zapomniano. Kiedy goście króla wyrażą już swoje uznanie dla opowieści i zasiądą do kolacji, nadworny malarz mówi karłowi, że po raz pierwszy słyszał tę historię w wykonaniu włoskiej trupy w Abruzzi. Nabo przyznaje, że nic takiego naprawdę mu się nie przydarzyło, lecz usłyszał o tym w Lizbonie, kiedy „podróżował z sułtanem z Aleksandrii”. Nie tylko Nabo opowiada jak klasyczny storyteller, przywłaszczając sobie i przetwarzając narrację, aby odpowiadała określonemu miejscu wykonania, ale także rozmowa tych dwóch przedstawicieli niższej klasy „obśmiewa"22 czy komentuje udawany kosmopolityzm wyższych klas, które zaślepione ideologią klasy i rasy nie dostrzegają ukrytego ostrza krytyki skierowanego przeciwko ich kulturowej ignorancji i nieuzasadnionym społecznym pretensjom. Ten dialog kończy się wyznaniem malarza, że mimo poczucia wyższości zawsze maluje elity tak, by wyglądały lepiej niż w rzeczywistości. Ten komentarz sam $\mathrm{w}$ sobie stanowi metakomentarz na temat siły sztuki, która może nieadekwatnie bądź zbyt idealistycznie reprezentować rzeczywistość, a później uważa się to za niepodważalny fakt.

Po gorących namowach malarza, by Nabo pozwolił się namalować, Luiza Maria Teresa pojawia się na scenie. Jest zarazem narratorem, który uruchomił całą akcję sztuki, jak i widzem oglądającym to, co dzieje się na scenie; jako storyteller kontroluje przebieg sekwencji narracyjnych i podejmuje $z$ nimi interakcję. Za sprawą magii opowieści i sztuki teatru wkracza nagle w akcję jako swój młodszy sobowtór, kiedy po wielu latach od rozmowy Nabo z malarzem spotyka tego samego malarza, który dostrzega jej podobieństwo do pewnego Afrykańczyka o imieniu, które błędnie zapamiętał jako Bobo. Jako storyteller może przekroczyć ograniczenia czasu, więc powraca do momentu, kiedy jej ojciec pozował do obrazu. Po chwili zwraca się wprost do widzów, mówiąc, że wiele lat później w jakiejś wilgotnej piwnicy znaleziono szkic, „porter bezimiennego Afrykańczyka”. W takich momentach publiczność ma okazję zauważyć, jak pewna operacja pamięci, związana również $\mathrm{z}$ mechanizmem zapominania, staje się materią dramatu. Niewinne zapominanie pogarsza jeszcze umyślnie podjęty, instytucjonalnie usankcjonowany akt zapominania albo błędnego zapominania, bo w jednej z późniejszych scen między Ludwikiem XIV i Nabo, król podpisuje wyrok śmierci na karła, skazując karła i jego dziecko, Luizę Marię Teresę na nieistnienie, choć przecież pozostawia też ślad ich nieobecności.

${ }^{22}$ Słowa „obśmiewać” (signify) używam w tym sensie, w jakim funkcjonuje ono w dialekcie czarnoskórych, którzy używają go w znaczeniu „komentować, często za pomocą złośliwych, błyskotliwych gier slów lub aluzji"; Por. G. Smitherman, Talkin and Testifyin..., op. cit., s. 82. 
Częścią tej pamięci jest również wyobraźnia - jak twierdzi afroamerykański pisarz Ralph Ellison - pamięć o tym, czym mogliśmy być ${ }^{23}$ oraz samo doświadczenie widzów pokazujące, jak można odzyskać to, co znajduje się na marginesach dominującej kultury. W tym miejscu warto wspomnieć o eseju Toni Morrison The Site of Memory (Miejsce pamięci), w którym wyjaśnia powody napisania powieści Ukochana. Morrison przekonuje, że ponieważ opowieści o niewolnikach, a więc pierwsze próby manifestowania własnej obecności przez Afroamerykanów, nie mówiły nic o ich życiu wewnętrznym, „wspomnienia i reminiscencje nie zapewnią mi pełnego dostępu do niezapisanego życia wewnętrznego tych ludzi. Tylko działanie wyobraźni może mi w tym pomóc". Nazywając ten proces mianem literackiej archeologii, pisze dalej: „Na podstawie wyrywkowych informacji i pewnych hipotez można odbyć podróż do miejsca, w którym można zobaczyć to, co pozostało, by na podstawie tych szczątków zrekonstruować tamten świat. To fikcja ze względu na samą naturę pracy wyobraźni: jej oparcie w obrazie - budowanym na podstawie szczątków któremu towarzyszy również wspominanie, co razem wytwarza pewien rodzaj prawdy. Obraz to dla mnie nie tyle «symbol», co raczej po prostu "obrazek", razem z towarzyszącymi mu uczuciami"24. Choć w przeciwieństwie do Femi Osofisana, Nottage nie prosi widzów, aby podjęli dyskusję na temat prawdziwości tej wersji historii, to jednak stawia przed nimi zadanie weryfikacji kłamstwa czy fikcji, którą tworzy storytelling i teatr. Morrison przypomina swoim czytelnikom, że „fakty mogą istnieć niezależnie od ludzkiej inteligencji, ale prawda już nie". Sytuując widzów w pozycji, którą Foucault nazwał „czystą odpowiedniością” obserwującego i obserwowanego, oraz pokazując jej marginalność, Las Meninas każe widzom zrewidować te narracje, które zostały skazane na nieistnienie przez rozpowszechnione opowieści i te wersje historii, których do tej pory się uczyli.

Wszystkie trzy omawiane przeze mnie sztuki - Once Upon Four Robbers Femi Osofisana, Gem of the Ocean Augusta Wilsona i Las Meninas Lynn Nottage - pokazują storytelling i teatr lub wyobraźnię jako istotne praktyki społeczne (Appadurai), w których wykonawcy i publiczność współpracują ze sobą, aby jeszcze raz przeanalizować i być może inaczej poukładać swój świat. Rozpoczęłam od polemiki z pewnym rozpowszechnionym w Europie i Stanach Zjednoczonych sposobem definiowania białej rasy w powiązaniu z kwestiami klasy społecznej i seksual-

23 J. Roach, Cities of the Dead, op. cit., s. 33.

${ }^{24}$ T. Morisson, The Site of Memory, w: Marginalization and Contemporary Cultures, red. Trinh T. Minh-ha, Martha Gever i Cornel West, MIT Press, Cambridge 1990, s. 299-305, tutaj s. 302 . 
ności, który utwierdza jej hegemoniczną wizję świata. Próbowałam udowodnić, że koncepcja storytelling jako nowej formy teatralnej, która ma przywrócić społeczne więzi, to tylko kwestia punktu widzenia; dla niektórych opowieść, rozumiana jako literatura oralna, pozostała istotnym sposobem doświadczania siebie w relacji do społeczności. Nie chcę jednak kończyć powrotem do starego i już zdewaluowanego, bo opartego na binarnej opozycji poglądu, że istnieje "Zachód i cała reszta”. Chciałabym raczej zasugerować, że pytanie, jakie zadaje Ciotka Ester Barlowowi, to również pytanie, na które powinniśmy spróbować odpowiedzieć wszyscy, zarówno w bardzo lokalnych, jak i regionalnych, narodowych, międzynarodowych i światowych kontekstach. Pyta ona bowiem: "Ile warte jest pańskie życie, Obywatelu Barlow?”. My powinniśmy zapytać: Ile warte jest nasze życie i czy umiemy zdać sobie sprawę z jego wartości $w$ relacji z naszymi bliźnimi dzięki „inscenizacji wielu możliwości”, jakie oferuje konwencja opowieści i teatr?

Przetożyli: Mateusz Borowski, Matgorzata Sugiera 